\title{
Executive Functions, Oral Language and Writing in Preschool Children: Development and Correlations ${ }^{1}$
}

\author{
Talita de Cassia Batista Pazeto ${ }^{2}$ \\ Universidade Presbiteriana Mackenzie, \\ São Paulo-SP, Brazil
}

\author{
Alessandra Gotuzo Seabra \\ Universidade Presbiteriana Mackenzie, \\ São Paulo-SP, Brazil
}

\author{
Natália Martins Dias \\ Centro Universitário FIEO, \\ Osasco-SP, Brazil
}

\begin{abstract}
Executive functions (EF) and oral language(OL) are important for learning reading and writing (RW) and for the development of other skills in preschool. The study investigated the progression and the relationships between the performances in these competences in pre-schoolers. Participants were 90 children, mean age 4.91 years, students from Kindergarten years I and II of a private school in SP, assessed, individually, with a battery with nine instruments for EF, OL, and RW. There was increase of the performances as a result of educational level for all OL and RW measures, but only for attention in the field of EF. Significant correlations were found between the measurements assessing the same cognitive domain, as well as inter-domain, although portraying a different pattern. The results indicate that OL and RW seem to develop rapidly in the course of preschool, while the EF have slower development. The fields of OL and RW, EF and RW are more interdependent, and EF and OL are relatively independent.
\end{abstract}

Keywords: cognitive development, evaluation, children, learning

\section{Funções Executivas, Linguagem Oral e Escrita em Crianças Pré-Escolares: Desenvolvimento e Correlações}

\begin{abstract}
Resumo: Funções executivas (FE) e linguagem oral (LO) são importantes para a aprendizagem da leitura e escrita (LE) e para o desenvolvimento de demais competências na fase pré-escolar. O estudo investigou a progressão e as relações entre os desempenhos nestas competências em pré-escolares. Participaram 90 crianças, idade média de 4,91 anos, estudantes do Jardim I e II de uma escola particular de SP, avaliadas, individualmente, em uma bateria de nove instrumentos de FE, LO e LE. Houve aumento dos desempenhos em função do nível escolar para todas as medidas de LO e LE, porém apenas para a medida de atenção no domínio das FE. Correlações significativas foram evidenciadas entre medidas que avaliam um mesmo domínio cognitivo, assim como interdomínios, ainda que retratando um padrão diferencial. Os resultados sugerem que LO e LE parecem desenvolver-se rapidamente no curso da pré-escola, enquanto as FE apresentam desenvolvimento mais lento. Os domínios de LO e LE, bem como FE e LE são mais interdependentes; enquanto FE e LO são relativamente mais independentes.
\end{abstract}

Palavras-chave: desenvolvimento cognitivo, avaliação, crianças, aprendizagem

\section{Funciones Ejecutivas, Lenguaje Oral y Escrito en los Niños en Edad Preescolar: Desarrollo y Correlaciones}

\begin{abstract}
Resumen: Las funciones ejecutivas (FE), el lenguaje oral (LO) son importantes para aprender a leer y escribir (LE) y para el desarrollo de otras habilidades en el período preescolar. El estudio investigó la evolución y las relaciones entre los rendimientos en estas habilidades en los niños preescolares. Participó en 90 niños, edad promedio de 4,91 años, estudiantes del Jardín I y II de una escuela privada en SP, evaluadas, de forma individual, con una batería con nueve instrumentos para FE, LO, y LE. Hubo un aumento en el rendimiento en función del nivel educativo en todas las medidas de LO y LE, pero sólo en la medida de atención en FE. Se encontraron correlaciones significativas entre las medidas que evalúan el mismo dominio cognitivo, así como inter-dominio, a pesar de representar un patrón diferencial. LO y LE parecen desarrollarse rápidamente en el curso de la enseñanza preescolar, mientras que FE tiene un desarrollo más lento. Los campos LO y LE, FE y LE son más interdependientes; FE y LO son relativamente independientes.
\end{abstract}

Palabras clave: desarrollo cognitivo, evaluación, niños, aprendizaje

\footnotetext{
${ }^{1}$ Paper derived from the master's thesis of the first author with the guidance of the second author, which was defended within the Graduate Program in Developmental Disorders, Mackenzie Presbyterian University, on December 4th, 2012.

Support: The Coordination for the Improvement of Higher Education Personnel (CAPES).

2 Correspondence address:

Talita de Cassia Batista Pazeto. Rua Conselheiro Dantas, 268, Canindé. CEP 03032-020. São Paulo-SP, Brazil. E-mail: talita.psicopedagoga@hotmail.com
}

The evaluation of preschool age children is of great importance, as it can assist in the investigation of how skills related to learning develop. In addition, it can contribute to the early detection of possible difficulties and assist in the planning of appropriate interventions and public policies. Studies have been undertaken in this population, aiming to identify and investigate learning-related skills (Araújo, 
Marteleto, \& Schoen-Ferreira, 2007; Maluf \& Barrera, 1997; Pereira, Seabra, Dias, Trevisan, \& Prado, 2012; Souza \& Avila, 2011; Trevisan, 2010). Among the areas studied, one can highlight three which have important development in the preschool phase and which have been consistently related to later outcomes, relative, in particular, to academic performance: the executive functions (Diamond, 2006, 2013; Pereira et al., 2012), oral language (Acosta, Moreno, Ramos, Quintana, \& Espino, 2006; Araújo et al., 2007; Maluf \& Barrera, 1997) and preliminary knowledge of reading and writing (Maluf \& Barrera, 1997; Shaywitz, 2006).

The executive functions refer to the individual's ability to undertake voluntary, independent, self-organized actions directed toward specific goals; they are considered one of the most complex aspects of cognition (Gazzaniga, Ivry, \& Mangun, 2006; Malloy-Diniz, Sedo, Fuentes, \& Leite, 2008). The term covers different cognitive skills, such as working memory, relating to the ability to support and manipulate information mentally; cognitive flexibility, which refers to the ability to change attentional focus or perspective and adapt the behavior to the demands of the environment; and inhibition, which involves both the skill of inhibiting the behavior and controlling attention and mental processes, inhibiting distractors and focusing attention (Diamond, 2013; Gazzaniga et al., 2006; Miyake et al., 2000; Nigg, 2001). There is evidence of these components of the executive functions already developing at preschool age (Diamond, 2006, 2013; Pereira, 2011; Pereira et al., 2012; Trevisan, 2010). Additionally, these skills have been related to learning (Diamond, 2006, 2013), emphasis being placed on their role in the competence of reading (Cutting, Materek, Cole, Levine, \& Mahone, 2009), mathematics (Blair \& Razza, 2007; Duncan et al., 2007) and in school performance in general, evaluated in terms of grades (Capovilla \& Dias, 2008a).

Another skill which has consistently featured as a predictor of later academic performance is oral language, defined as the individual use of the codes of a system formed of a limited number of minimum units, which are recombined according to predetermined rules. Language can be separated into different components, such as semantic, syntactic, phonological, morphemic and pragmatic (Sternberg, 2008) and develops at an accelerated rate during the preschool age, there being reports of significant differences between school years for vocabulary and phonological awareness (Capovilla \& Capovilla, 1997; Ferracini, 2005; Ferracini, Capovilla, Dias, \& Capovilla, 2006; Maluf \& Barrera, 1997). There is also evidence that different aspects of oral language, including vocabulary, phonological awareness and rapid naming skills predict performance in written language (Aaron, Joshi, \& Quatroche, 2008; Capovilla \& Dias, 2008b; Cardoso-Martins, 2008; Cardoso-Martins \& Pennington, 2001; Maluf \& Barrera, 1997; Seabra \& Dias, 2012a; Zorzi, 2009). Alterations in oral language can importantly affect children's social and cognitive development. As a result, its evaluation at early ages is being increasingly emphasized in the literature.
In addition to the executive functions and oral language, preliminary knowledge of reading and writing, which also develops in the preschool phase, has a significant relationship with later academic performance. In spite of the broad literature on written language, including evaluation and intervention, even in the Brazilian ambit, (Batista \& Capellini, 2011; Joly \& Piovezan, 2012; Monteiro \& Santos, 2013; Seabra \& Dias, 2012a), the evaluation of the beginning of reading and writing in preschool children has been less explored, such that their development and the pattern of relationships which is established with other cognitive domains - which is relatively well-known in children of school age - is practically unknown (Aaron et al., 2008; Cutting et al., 2009; Seabra \& Dias, 2012a). Internationally, however, there is evidence that preliminary competence in reading and writing is a strong predictor of later performance in reading and in mathematics (Duncan et al., 2007).

In the light of this panorama, this study evaluated the initial executive functions, oral language and reading and writing in preschool children with the following objectives: (1) to ascertain if the children's performances improve as they progress through school, even at relatively early ages; and (2) to investigate how these separate cognitive domains correlate with each other. Studies with preschool children are relatively scarce in the Brazilian context, such that the results of the present study could help to support a better understanding regarding the development of the distinct skills evaluated in this age range, as well as to understand the cognitive architecture in this initial phase of child development.

\section{Method}

\section{Participants}

The sample was initially made up of 94 children enrolled in the Kindergarten years I and II in a private school in the central region of the city of São Paulo. Four children were excluded from the subsequent analyses due to intellectual disabilities or to medical diagnoses of genetic or neurodevelopmental issues. After the exclusions, the final sample was made up of 90 children (Mean age $=4.91$ years old), enrolled in the Kindergarten years I $(N=37)$ and II $(N=53)$ of a private school in the central region of the city of São Paulo. Table 1 presents data characterizing the sample.

\section{Instruments}

Semantic Stroop Test. This aims to evaluate selective attention and inhibitory control in children. The version adapted by Trevisan (2010) was used, based on the versions of Berwid et al. (2005) and Brocki and Bohlin (2006). The test is computerized and divided in two parts, each one presenting 16 pictures (girl, boy, sun and moon). In the first part of the test, the child names the pictures presented on the computer screen, and in the second must name the 
Pazeto, T. C. B., Seabra, A. G., \& Dias, N. M. (2014). Executive Functions and Language in Preschoolers.

Table 1

Characterization of the Sample: Frequency by Sex and the Mean Age at Each School Level and in Total

\begin{tabular}{lcccccc}
\hline \multirow{2}{*}{ School year } & \multicolumn{3}{c}{ Sex (frequency) } & \multicolumn{3}{c}{ Age } \\
\cline { 2 - 6 } & Boys & Girls & Total by year & Mean & Minimum & Maximum \\
\hline K'ten I & 19 & 18 & 37 & 4.35 & 4 & 5 \\
K'ten II & 27 & 26 & 53 & 5.30 & 5 & 5 \\
Total & 46 & 44 & 90 & 4.91 & 4 & 5 \\
\hline
\end{tabular}

opposite noun (for example, say 'moon' when the picture of the sun appears). The measures of interference were used (performance in part two minus performance in part one), both for the score and for the reaction time (RT).

Trail-making Test for Pre-schoolers (TT-PS). The TT-PS (Trevisan \& Seabra, 2012) evaluates cognitive flexibility. It was adapted from parts A and B of the Trail-making Test, which is originally made up of numbers and letters. The adaptation for pre-schoolers was based on the versions of Baron (2004), Espy (1997), Espy and Cwik (2004) and Espy, Kaufmann, Glisky and McDiarmid (2001). In this version, knowledge of letters and numbers is not necessary, as it is in the original version. Part A is made up of pictures of five dogs (described to the child as youngest puppy, middle puppy, oldest puppy, and mommy and daddy) and the child must link them in order of size. In part B, in addition to the dogs, pictures of bones are added, in sizes equivalent to each dog; the child's task is to link the dogs to the bones, in order of size and alternating between the stimuli. Performance in sequences was used (number of items linked correctly in a sequence until error or interruption) in both parts of the test.

Cancellation Attention Test (CAT). The CAT (Montiel \& Seabra, 2012) is made up of three phases. In the first of these, the child is presented with a target stimulus and is invited to indicate all stimuli identical to the target among various others in a matrix. The task is the same in the second part, although the target stimulus is made up of double figures. In the third part, the target stimulus changes with each line of the matrix. The test aims to evaluate selective attention (parts 1, 2 and 3) and ability to alternate attention (part 3). There is a time limit of one minute for each part of the test. The total number of correct answers in the test was used.

The Phonological Awareness Test by Oral Production (PAT-OP). The PAT-OP (Seabra \& Capovilla, 2012) aims to evaluate the skill of manipulating the sounds of speech. A total of 10 components of phonological awareness are evaluated over 10 subtests, each one containing four items and two initial examples: Syllabic Synthesis; Phonemic Synthesis; Rhyme; Alliteration; Syllable segmentation; Phoneme segmentation; Syllabic Manipulation; Phonemic Manipulation; Syllabic Transposition and Phonemic Transposition. For each correct response, the child receives one point, totaling a maximum of 40 points. The total score was used in the PAT-OP.

The Peabody Picture Vocabulary Test (PPVT). The computerized version adapted by Capovilla and Capovilla (1997) was used. The instrument is based in the version of Dunn and Dunn (1981) and aims to evaluate receptive vocabulary. As a result, the ability to understand vocabulary in various categories is evaluated (persons, actions, qualities, parts of the body, weather, nature, places, objects, animals, mathematical terms, tools and instruments). This version of the PPVT presents 125 screens, each one with four pictures in black and white. The computer emits one spoken word and the examinee must choose the image which corresponds to this word, pointing to the picture on the screen. The total number of correct answers was used.

The Child Naming Test (CNT). The CNT (Seabra, Trevisan, \& Capovilla, 2012) aims to evaluate the expressive vocabulary and the skill in naming. It is made up of 60 line drawings which represent objects (e.g. a chair, a sword); animals (e.g. a dog, an elephant) and people (e.g. a nun, a baby). The test is administered using a notebook containing two pictures per page. The examiner shows the notebook with images and notes down, on the response sheet, the examinee's naming. The total number of correct answers in the test was used.

Pseudowords and Words Repetition Test (PWRT). The PWRT (Seabra, 2012) aims to evaluate the shortterm phonological memory. The evaluator pronounces for the child various sequences made of two to six words, maintaining an interval of one second between them. The child's task is to receive the information, store it, and return it in the form of repeating the same sequence which was presented to her. Afterwards, the procedure is repeated, although using pseudowords. The number of correct answers (sequences repeated correctly) in words, and the number of correct answers in pseudowords, were used.

Recognition of Letters and Sounds Test. This test was developed specifically for this study, with the aim of ascertaining the child's knowledge in naming the letters and saying their sounds. Each letter, including vowels and consonants, is printed in block letters and presented to the examinee on a sheet of paper. The order of presentation is random. The same sequence is maintained for all the children, alphabetical order not being followed. In the first administration, the child must name the letter; afterwards, the procedure is repeated, but the child is instructed to pronounce the sound of the letter. The score can vary from 0 to 26 points in the letters and in the sounds. In the sounds, it is considered correct when the child says that the letter $\mathrm{H}$ has no sound and the Y has the sound of I. The total number of correct answers in the part of letters and the total number of correct answers in the part of sounds were used as scores. 
It is emphasized that, as this test was developed specifically for the present study, there are no standards expected for this educational level; however, as in the school of the participants in this study, the teaching of the alphabet begins in Kindergarten year I, and literacy begins in year II, one can hypothesize that the children already have some knowledge for responding to the test.

The Reading and Writing Test. Developed specifically for the present study, this test is made up of two phases. In the first, the child receives a sheet with eight words and two pseudowords to read, and, in the second, eight words and two pseudowords are dictated for the child to write down. The words progress in order of difficulty and are classified as: regular, of high frequency: regular, low frequency: irregular, high frequency: irregular, low frequency: and pseudowords. The correction is made calculating the percentage of correct answers per item, through the calculation of the quantity of letters which the child read correctly and the quantity of letters which she wrote correctly. Performance can vary from 0 to $100 \%$ in reading and from 0 to $100 \%$ in writing.

With the exception of the Recognition of Letters and Sounds Test and the Reading and Writing Test, which were developed specifically for this study, the instruments have psychometric characteristics, including evidence of validity and reliable data, for pre-school samples, already published in the literature (Ferracini et al., 2006; Seabra \& Dias, 2012b, 2012c; Trevisan, 2010).

\section{Procedure}

Data collection. Collection occurred in the periods of May - June and August - September 2012, in a room set aside for the purpose by the school, and during regular lesson times. The children were removed from the room, individually, for short periods of time, varying from five to 15 minutes, with the authorization of the teacher and the consent of student. Six sessions were necessary with each student for administering the tests, as, these being pre-school children, it was sought to reduce the variable of tiredness. The tests were divided into six sessions: Session 1 - The Peabody Picture Vocabulary Test; Session 2 - The Trail-making Test for Preschoolers and the Cancellation Attention Test; Session 3 Test of Recognition of Letters and Test of Recognition of Sounds; Session 4 - The Phonological Awareness Test by Oral Production; Session 5 - The Child Naming Test, The Pseudowords and Words Repetition Test, the Reading and Writing Test; and Session 6 - The Semantic Stroop Test.

There was an interval of 3 to 4 days between the removal of the child from the classroom for one test and the next. After the finalization of the data collection, feedback was provided to the parents and the school. Individual reports were elaborated for the parents with the performance of each one of the children in all the tests administered, already standardized for the Brazilian population, comparing them with their peers from the same school year. Feedback meetings were held for the school directors and teachers.
Data analysis. In order to ascertain the progression of performance in the various tests related to school level, the Student $t$ test was applied, with the school year (Kindergarten years I and II) as factors, and the measurements in the various tests as the dependent variables. In order to investigate the relationships between the performances in the various measures, the Pearson correlation analysis was used. In all the cases, the level of significance of $p \leq .05$ was adopted.

\section{Ethical Considerations}

The project was first of all submitted to the Research Ethics Committee of the Universidade Presbiteriana Mackenzie under process number CAAE 02631312.3.0000.0084. Following its approval, contact was made with the school and letters containing the terms of free and informed consent, as well as information about the research, were sent to those responsible for the institution and for the children.

\section{Results}

Student $t$ tests were applied to verify the effects of school level on the performances in each test. Table 1 presents the descriptive and inferential statistics, with values of $t$ and $p$, for the measurements of executive functions, oral language, reading and writing. For executive functions, only the measurements of the CAT were significantly affected by school level. The performances in the Trail-making Test and Stroop Test did not show an effect of school progression from Kindergarten year I to year II. On the other hand, the performances in all the measurements of oral language, reading and writing showed the school year to have a significant effect. The results summarize the increase in the performance in tasks which evaluate different cognitive domains with progression in school years.

Table 3 presents the matrix of correlations between performance in the tests of executive function, oral language, reading and writing. Significant correlations are printed in bold. The relationships tended to be more consistent, in spite of the variation of scale, between the performances in tests on one same domain, at least for oral language (with variation between .22 and .59) and reading and writing (with variation between .27 and .87). For executive functions, only the measurement of interference reaction time in the Stroop Test was related, to a moderate degree, with the interference score in the same test and, to a lesser degree, with the number of correct answers in the Cancellation Attention Test. This correlation suggests that children with a greater interference time, that is, who took more time in the second part of the test, tended to have better performances in the Cancellation Attention Test and in the second part of the Stroop Test. The data indicates that these children could have responded more slowly, while preserving their accuracy.

Considering the correlations between the cognitive domains, these were low to high, all were significant and positive, among the performance in the tests of oral language 
Pazeto, T. C. B., Seabra, A. G., \& Dias, N. M. (2014). Executive Functions and Language in Preschoolers.

Table 2

Descriptive and Inferential Statistics of the Effect of School Level on Performance in the Various Instruments

\begin{tabular}{|c|c|c|c|c|c|}
\hline & \multicolumn{4}{|c|}{ School level } & \multirow{3}{*}{$t$} \\
\hline & \multicolumn{2}{|c|}{ Kindergarten I } & \multicolumn{2}{|c|}{ Kindergarten II } & \\
\hline & $M$ & $S D$ & $M$ & $S D$ & \\
\hline TT-PS - sequence A & 3.11 & 1.51 & 3.68 & 1.70 & -1.65 \\
\hline TT-PS - sequence B & 2.30 & 1.13 & 2.7 & 1.96 & -1.12 \\
\hline CAT - part 1 - correct answers & 23.16 & 9.64 & 29.89 & 7.89 & $-3.63 * *$ \\
\hline CAT - part 2 - correct answers & 0.81 & 0.91 & 1.51 & 1.12 & $-3.14 * *$ \\
\hline CAT - part 3 - correct answers & 7.73 & 4.12 & 12.6 & 4.63 & $-5.14 * *$ \\
\hline CAT - total - correct answers & 31.70 & 11.82 & 44 & 10.30 & $-5.25 * *$ \\
\hline Stroop-interference-score & -0.34 & 0.32 & -0.26 & 0.24 & -1.35 \\
\hline Stroop-interference-RT & 0.53 & 0.73 & 0.63 & 0.47 & -0.79 \\
\hline CNT & 26.9 & 5.96 & 33.62 & 5.54 & $-5.47 * *$ \\
\hline PAT-OP & 10.1 & 3.66 & 18.95 & 8.21 & $-6.17 * *$ \\
\hline PWRT_Words & 2.73 & 0.93 & 3.58 & 1.35 & $-3.33^{* *}$ \\
\hline PWRT_Pseudowords & 1.51 & 0.77 & 1.91 & 0.71 & $-2.48^{*}$ \\
\hline PWRT_Total & 4.24 & 1.16 & 5.49 & 1.73 & $-3.82 * *$ \\
\hline PPVT & 57.35 & 6.83 & 64.15 & 7.30 & $-4.46^{* *}$ \\
\hline Knowledge of letters & 18.19 & 6.96 & 22.68 & 3.49 & $-4.03 * *$ \\
\hline Knowledge of sounds & 2.54 & 4.45 & 16.75 & 6.50 & $-11.54 * *$ \\
\hline Test of reading & 0.61 & 2.73 & 51.67 & 43.54 & $-7.11 * *$ \\
\hline Test of writing & 9.1 & 13.35 & 64.54 & 29.94 & $-10.54 * *$ \\
\hline
\end{tabular}

${ }^{*} p<.05 .{ }^{* *} p<.01$.

Table 3

Matrix of Correlations Between Performance in the Various Instruments

\begin{tabular}{|c|c|c|c|c|c|c|c|c|c|c|c|c|c|}
\hline & $\begin{array}{l}\text { TT-PS } \\
\text { Seq_A }\end{array}$ & $\begin{array}{l}\text { TT-PS } \\
\text { Seq_B }\end{array}$ & $\begin{array}{l}\text { CAT- } \\
\text { total }\end{array}$ & $\begin{array}{l}\text { Stroop- } \\
\text { interf- } \\
\text { score }\end{array}$ & $\begin{array}{l}\text { Stroop- } \\
\text { interf-RT }\end{array}$ & PPVT & PAT-OP & PWRTWords & PWRTPseudo & CNT & $\begin{array}{l}\text { Knowl. } \\
\text { letters }\end{array}$ & $\begin{array}{l}\text { Knowl. } \\
\text { sounds }\end{array}$ & $\begin{array}{l}\text { Test of } \\
\text { reading }\end{array}$ \\
\hline TT-PS Seq_B & .20 & & & & & & & & & & & & \\
\hline CAT-total & .08 & .15 & & & & & & & & & & & \\
\hline $\begin{array}{l}\text { Stroop-interf- } \\
\text { score }\end{array}$ & .11 & .10 & .07 & & & & & & & & & & \\
\hline $\begin{array}{l}\text { Stroop- } \\
\text { interf-RT }\end{array}$ & .13 & .05 & $.26^{*}$ & $.45^{* *}$ & & & & & & & & & \\
\hline PPVT & $.21^{*}$ & $.29 * *$ & $.43 * *$ & .16 & .04 & & & & & & & & \\
\hline PAT-OP & $.30^{* *}$ & $.28 * *$ & $.34 * *$ & $.26^{*}$ & .20 & $.51 * *$ & & & & & & & \\
\hline PWRT-words & $.22 *$ & .11 & .09 & .19 & .19 & .16 & $.39 * *$ & & & & & & \\
\hline $\begin{array}{l}\text { PWRT- } \\
\text { pseudo }\end{array}$ & .10 & -.08 & $.32 * *$ & .20 & .13 & $.29 * *$ & $.22 * *$ & $.26^{*}$ & & & & & \\
\hline CNT & .16 & .20 & $.39 * *$ & $.32 * *$ & $.28 * *$ & $.58 * *$ & $.59 * *$ & $.34 * *$ & $.39 * *$ & & & & \\
\hline Knowl. letters & $.27 * *$ & .08 & $.41 * *$ & .03 & $.24 *$ & $.44 * *$ & $.51 * *$ & $.24^{*}$ & $.29 * *$ & $.54 * *$ & & & \\
\hline $\begin{array}{l}\text { Knowl. } \\
\text { sounds }\end{array}$ & $.36^{* *}$ & .20 & $.49 * *$ & $.22 *$ & .20 & $.53 * *$ & $.74 * *$ & $.26^{*}$ & $.30 * *$ & $.57 * *$ & $.55^{* *}$ & & \\
\hline $\begin{array}{l}\text { Test of } \\
\text { reading }\end{array}$ & .19 & .20 & $.34 * *$ & .10 & .11 & $.40 * *$ & $.76^{* *}$ & $.30 * *$ & $.24^{*}$ & $.41 * *$ & $.49 * *$ & $.73 * *$ & \\
\hline $\begin{array}{l}\text { Test of } \\
\text { writing }\end{array}$ & $.25^{*}$ & $.21^{*}$ & $.49 * *$ & .14 & .16 & $.50 * *$ & $.80 * *$ & $.33 * *$ & $.27^{*}$ & $.56^{* *}$ & $.57 * *$ & $.87 * *$ & $.81 * *$ \\
\hline
\end{tabular}

$* p<.05 . * * p<.01$.

and reading and writing (with variation between .24 and .80). Some significant relationships, from low to moderate, were also evidenced between the performances in executive functions and reading and writing (with variation between .21 and .49). The less consistent correlations, in which only the low relationships predominated, were between performance in the executive functions and oral language (with variation between .21 and .43).

\section{Discussion}

The results of the analyses of the effects of school level on performance revealed some tendencies of development. The increase in performance as the children progress through school was expected (Almeida, Lemos, Guisande, \& Primi, 2008; Batista \& Capellini, 2011; Capovilla \& Dias, 2008a; Dias, Menezes, \& Seabra, 2013; Ferracini, 2005; Pereira 
et al., 2012; Trevisan, 2010), as indeed occurred. For oral language, reading and writing, the children from Kindergarten II performed better than their younger peers. Although the present study is correlational, and did not accompany the children longitudinally, this result corroborates evidence that these skills develop rapidly over one year of schooling (Ferracini, 2005; Ferracini et al., 2006; Storch \& Whitehurst, 2002), even in pre-school.

In relation to the oral language tests, the results showed that, in relation to the younger peers of Kindergarten I, the children of Kindergarten II had higher scores in vocabulary, phonological memory, and phonological awareness, this last being fundamental for acquiring written language (Aaron et al., 2008; Capovilla \& Dias, 2008b; Seabra \& Dias, 2012a). These findings corroborate the research of Ferracini (2005), who also observed the effect of school year in her evaluation in Brazilian pre-schoolers. Similarly, the effect of school year on reading and writing occurred for all the measurements. This suggests that these domains are in full development in this sample, which is to be expected given that, in the school evaluated, the formal teaching of knowledge related to literacy, such as teaching letters and their sounds, is begun at these school levels, particularly in Kindergarten II, in which reading and writing proper begin to be taught.

For the executive functions, on the other hand, only the measuring of attention showed the effect of school level. It is possible that the other instruments, the Trail-making Test for pre-schoolers and the Stroop Test, were not sufficiently sensitive to discriminate between the different levels of the pre-school. Another explanation, however, is also possible, and considers the aspects of the development of these skills. That is, there is evidence that the executive functions have different developmental tendencies, with some skills developing before others (Diamond, 2013; Dias et al., 2013).

Thus, in relation to cognitive flexibility, evidence suggests that this is a more complex skill, whose development begins later and continues through to mid-adolescence (Diamond, 2013). Inhibitory control, on the other hand, can be divided in inhibition of response and in control of interference, which involves cognitive inhibition (Diamond, 2013; Nigg, 2001), this last developing later. Thus, one can raise the hypothesis that the absence of differences between the school levels in the cognitive flexibility and inhibitory control tests may reflect these skills' early stage of development in the age range evaluated.

Regarding the analyses of correlation, consistent correlations were ascertained between the performances in tests in one same domain, considering oral language and written language. In particular regarding the skills of oral language, there were significant correlations between all the measurements. This finding supports the theoretical perspective that the skills measured are aspects of a single construct and corroborates the use of such instruments for evaluating these skills, as well as the joint use for a more comprehensive and detailed evaluation. This pattern of correlations is supported by Ferracini's (2005) results, also with pre-schoolers.

There were also significant correlations between all the measurements of reading and writing. It is of relevance to observe that reading and writing had greater correlations with knowledge of sounds than with knowledge of letters, reinforcing the importance of this skill for literacy, as already indicated by Cardoso-Martins (2008) and Zorzi (2009).

Considering the executive functions, there was moderate correlation only between the performances in the Stroop Test (interference in terms of score and reaction time); there was low correlation between these and the total score in the Cancellation Attention Test. The Trail-making Test for Pre-schoolers was not correlated with any other measurement of executive function. These results may be due to the as-yet incipient development of these skills. Furthermore, the pattern of results corroborates the idea that the different skills which are components of the executive functions are interrelated, although this relationship is generally low (Miyake et al., 2000), which was also observed in Brazilian studies with children by Dias (2009) and Pereira (2011).

The relationships between the domains revealed some patterns which were expected, such as, for example, the relationships between the performance in the tasks of oral language and written language, showing that, even at pre-school age, they are strongly related. Above all, the performance in phonological awareness was related very highly and highly with performance in writing and reading, respectively, reinforcing the importance of this metalinguistic skill for literacy (Capovilla \& Dias, 2008b; Cardoso-Martins, 2008; Seabra \& Dias, 2012 ${ }^{\mathrm{a}}$; Zorzi, 2009).

The executive functions also presented some relationships with reading and writing, above all when the measurement of attention is considered. In the older children, undertaking Primary Education, this relationship has already been established (Cutting et al., 2009), although it remains little explored in pre-schoolers. The results found here suggest that, even in early ages, and in a mild form, the executive functions are related to reading and writing, which was also observed by Diamond (2006) and by Duncan et al. (2007).

Among the relationships established between executive functions and oral language, all were low, apart from a moderate relationship between performance in attention and vocabulary. This may mean that these skills are more independent one of the other. As a result, the pattern of correlations found shows that both executive functions and (and mainly) oral language are related to performance in reading and writing, which has already been documented in older children (Aaron et al., 2008; Cutting et al., 2009; Seabra \& Dias, 2012a), although executive functions and oral language appear to be relatively more independent between each other.

The results summarized here are important, given that there is little research, especially in Brazil, regarding 
Pazeto, T. C. B., Seabra, A. G., \& Dias, N. M. (2014). Executive Functions and Language in Preschoolers.

cognitive development in children in this age range. As a conclusion, this study's results can serve as a benchmark for the development of typical children, making it possible to evaluate and detect possible delays in various skills. They can serve, furthermore, as an indicator that there is a relationship between the domains evaluated in this educational level, suggesting that the development of one cognitive area or aspect is related to that of another. Hence, in spite of this study being correlational and not deriving from relationships of cause and effect, it is possible to suppose that the difficulties in reading and writing may be mitigated with interventions also in oral language and in the executive functions. Future studies could monitor children longitudinally to ascertain, more appropriately, the predictive power of different skills in relation to literacy, as well as investigating whether interventions in oral language and executive functions can mitigate problems in reading and writing.

Among the study's limitations, emphasis is placed on its transversal design and the relatively small number of participants, which limit generalization regarding the development of skills measured in the age range considered here. It also deserves to be noted that the study was limited to the investigation of the executive functions, oral language, reading and writing, although other competences develop during the pre-school years and are also relevant for learning. As a result, future studies could extend not just the sample, addressing other age ranges too, but also the scope of the skills measured.

\section{Final Considerations}

In conclusion, the present study showed that executive functions, oral language and written language increase with school progression, even in little children, such as those evaluated here. The development of oral language, reading and writing seems to be fairly pronounced in the progression from Kindergarten I to II, while that of the executive functions remains incipient or slower in this age range. In addition, it was ascertained that the skills and the domains of executive functions, oral language and reading and writing are significantly inter-related and that the pattern of relationships between the different domains is distinct. Thus, the domains of oral language and reading and writing, followed by executive functions and reading and writing are more interdependent, while there is a lesser relationship between executive functions and oral language. The results may contribute to broadening the knowledge available regarding the cognitive functioning of pre-school children, which could provide greater understanding regarding difficulties observed in this age range, as well as making it possible to evaluate and identify problems in the skills considered here and, as a consequence, to introduce interventions at early ages.

\section{References}

Aaron, P. G., Joshi, R. M., \& Quatroche, D. (2008). Becoming a professional reading teacher. Baltimore, MD: Paul H. Brookes.

Acosta, V. M., Moreno, A., Ramos, V., Quintana, A., \& Espino, O. (2006). Avaliação da linguagem: Teoria e prática do processo de avaliação do comportamento linguístico infantil. São Paulo, SP: Santos Editora.

Almeida L. S., Lemos, G., Guisande, M. A., \& Primi, R. (2008). Inteligência, escolarização e idade: Normas por idade ou série escolar? Avaliação Psicológica, 7(2), 117-125.

Araújo, M. V. M., Marteleto, M. R. F., \& Schoen-Ferreira, T. H. (2007). Avaliação do vocabulário receptivo de crianças pré-escolares. Estudos de Psicologia, 27(2), 169-176. doi:10.1590/S0103-166X2010000200004

Baron, I. S. (2004). Neuropsychological evaluation of the child. New York, NY: Oxford University Press.

Batista, A. O., \& Capellini, S. A. (2011). Desempenho ortográfico de escolares do $2^{\circ}$ ao $5^{\circ}$ ano do ensino privado do município de Londrina. Psicologia Argumento, 29(67), 411-425.

Berwid, O. G., Kera, E. A. C., Marks, D. J., Santra, A., Bender, H. A., \& Halperin, J. M. (2005). Sustained attention and response inhibition in preschool children at-risk for Attention Deficit/Hyperactivity Disorder. Journal of Child Psychology \& Psychiatry, 46(11), 12191229. doi:10.1111/j.1469-7610.2005.00417.x

Blair, C., \& Razza, R. P. (2007). Relating effortful control, executive function, and false-belief understanding to emerging math and literacy ability in kindergarten. Child Development, 78(2), 647-663. doi:10.1111/j.14678624.2007.01019.x

Brocki, K. C., \& Bohlin, G. (2006). Developmental change in the relation between executive functions and symptoms of $\mathrm{ADHD}$ and co-occurring behaviour problems. Infant and Child Development, 15(1), 19-40. doi:10.1002/icd.413

Capovilla, A. G. S., \& Dias, N. M. (2008a). Desenvolvimento de habilidades atencionais em estudantes da $1^{\mathrm{a}}$ à $4^{\mathrm{a}}$ série do ensino fundamental e relação com rendimento escolar. Revista Psicopedagogia, 25(78), 198-211.

Capovilla, A. G. S., \& Dias, N. M. (2008b). Habilidades de linguagem oral e sua contribuição para a posterior aquisição de leitura. Psic, 9(2), 135-144.

Capovilla, F. C., \& Capovilla, A. G. S. (1997). Desenvolvimento linguístico na criança dos dois aos seis anos: Tradução e estandardização do Peabody Picture Vocabulary Test de Dunn \& Dunn, e da Language Development Survey de Rescorla. Ciência Cognitiva: Teoria, Pesquisa e Aplicação, 1(1), 353-380.

Cardoso-Martins, C. (2008). Desenvolvimento das habilidades de leitura e escrita. In D. Fuentes, L. F. Malloy-Diniz, C. H. P. Camargo, \& R. M. Cosenza (Orgs.), Neuropsicologia: Teoria e prática (pp. 151-167). Porto Alegre, RS: Artmed. 
Cardoso-Martins, C., \& Pennington, B. (2001). Qual é a contribuição da nomeação seriada rápida para a habilidade de leitura e escrita? Evidência de crianças e adolescentes com e sem dificuldades de leitura. Psicologia: Reflexão e Crítica, 14(2), 387-397. doi:10.1590/S0102-79722001000200013

Cutting, L. E., Materek, A., Cole, C. A. S., Levine, T. M., \& Mahone, E. M. (2009). Effects of fluency, oral language, and executive function on reading comprehension performance. Annals of Dyslexia, 59(1), 34-54. doi:10.1007/s11881-009-0022-0

Diamond, A. (2006). The early development of executive functions. In E. Bialystok \& F. I. M. Craik (Eds.), Lifespan cognition: Mechanisms of change (pp. 70-95). New York, NY: Oxford University.

Diamond, A. (2013). Executive functions. Annual Review of Psychology, 64, 135-168. doi:10.1146/annurevpsych-113011-143750

Dias, N, M. (2009). Avaliação neuropsicológica das funções executivas: Tendências desenvolvimentais e evidências de validade de instrumentos (Unpublished master's thesis). Universidade Presbiteriana Mackenzie, São Paulo, SP.

Dias, N. M., Menezes, A., \& Seabra, A. G. (2013). Age differences in executive functions within a sample of Brazilian children and adolescents. The Spanish Journal of Psychology, 16, E9. doi:10.1017/sjp.2013.12

Duncan, G. J., Dowsett, C. J., Claessens, A., Magnuson, K., Huston, A. C., Klebanov, P., ... Japel, C. (2007). School readiness and later achievement. Developmental Psychology, 43(6), 1428-1446. doi:10.1037/00121649.43.6.1428

Dunn, L. M., \& Dunn, L. M. (1981). Peabody Picture Vocabulary Test - Revised. Circle Pines, MN: American Guidance Service.

Espy, K. A. (1997). The shape school: Assessing executive function in preschool children. Developmental Neuropsychology, 13(4), 495-499. doi:10.1080/87565649709540690

Espy, K. A., \& Cwik, M. F. (2004). The development of a trail making test in young children: The Trails-P. The Clinical Neuropsychologist, 18(3), 411-422. doi:10.1080/138540409052416

Espy, K.A., Kaufmann, P. M., Glisky, M. L., \& McDiarmid, M. D. (2001). New procedures to assess executive functions in preschool children. The Clinical Neuropsychologist, 15(1), 46-58. doi:10.1076/clin.15.1.46.1908

Ferracini, F. (2005). Evidências de validade de instrumentos para avaliação de linguagem oral em pré-escolares (Unpublished master's thesis). Universidade São Francisco, Itatiba, SP.

Ferracini, F., Capovilla, A. G. S., Dias, N. M., \& Capovilla, F. C. (2006). Avaliação de vocabulário expressivo e receptivo na educação infantil. Revista Psicopedagogia, 23(71), 124-133.
Gazzaniga, M. S., Ivry, R. B., \& Mangun, G. R. (2006). Neurociência cognitiva: A biologia da mente. Porto Alegre, RS: Artmed.

Joly, M. C. R. A., \& Piovezan, N. M. (2012). Avaliação do programa informatizado de leitura estratégica para estudantes do ensino fundamental 1. Paidéia (Ribeirão Preto), 22(51), 83-90. doi:10.1590/S0103-863X2012000100010

Malloy-Diniz, L. F., Sedo, M., Fuentes, D., \& Leite, W. B. (2008). Neuropsicologia das funções executivas. In D. Fuentes, L. F. Malloy-Diniz, C. H. P. Camargo, \& R. M. Cosenza (Orgs.), Neuropsicologia: Teoria e prática (pp. 187-206). Porto Alegre, RS: Artmed.

Maluf, M. R., \& Barrera, S. D. (1997). Consciência fonológica e linguagem escrita em pré-escolares. Psicologia: Reflexão e Crítica, 10(1), 125-145. doi:10.1590/S0102-79721997000100009

Miyake, A., Friedman, N. P., Emerson, M. J., Witzki, A. H., Howerter, A., \& Wager, T. D. (2000). The unity and diversity of executive functions and their contributions to complex "Frontal Lobe" tasks: A latent variable analysis. Cognitive Psychology, 41(1), 49-100. doi:10.1006/cogp.1999.0734

Monteiro, R. M., \& Santos, A. A. A. (2013). Recursos familiares e desempenho de crianças em compreensão de leitura. Psico, 44(2), 273-279.

Montiel, J., \& Seabra, A. G. (2012). Teste de atenção por cancelamento. In A. G. Seabra \& N. M. Dias (Orgs.), Avaliação neuropsicológica cognitiva: Atenção e funções executivas (Vol. 1, pp. 57-66). São Paulo, SP: Memnon.

Nigg, J. T. (2001). Is ADHD a disinhibitory disorder? Psychological Bulletin, 127(5), 571-598. doi:10.1037/0033-2909.127.5.571

Pereira, A. P. P. (2011). Desenvolvimento de funções executivas em crianças sem domínio da linguagem escrita e relação com desatenção e hiperatividade (Unpublished master's thesis). Universidade Presbiteriana Mackenzie, São Paulo, SP.

Pereira, A. P. P., Seabra, A. G., Dias, N. M., Trevisan, B. T., \& Prado, J. M. (2012). Funções executivas em crianças préescolares: Desenvolvimento da atenção seletiva medida pelo Teste de Atenção por Cancelamento. Cadernos de Psicopedagogia. Retrieved from http://pepsic.bvsalud. org/pdf/cap/2011nahead/a05.pdf

Seabra, A. G. (2012). Teste de repetição de palavras e pseudopalavras. In A. G. Seabra \& N. M. Dias (Orgs.), Avaliação neuropsicológica cognitiva: Linguagem oral (Vol. 2, pp. 97-99). São Paulo, SP: Memnon.

Seabra, A. G., \& Capovilla, F. C. (2012). Prova de consciência fonológica por produção oral. In A. G. Seabra \& N. M. Dias (Orgs.), Avaliação neuropsicológica cognitiva: Linguagem oral (Vol. 2, pp. 117-122). São Paulo, SP: Memnon.

Seabra, A. G., \& Dias, N. M. (2012a). Reconhecimento de palavras e compreensão de leitura: Dissociação e habilidades linguístico-mnemônicas preditoras. Revista Neuropsicologia Latinoamericana, 4(1), 43-56. doi:10.5597/rln.2012.01.01 
Seabra, A. G., \& Dias, N. M. (2012b). Avaliação neuropsicológica cognitiva: Atenção e funções executivas (Vol. 1). São Paulo, SP: Memnon.

Seabra, A. G., \& Dias, N. M. (2012c). Avaliação neuropsicológica cognitiva: Linguagem oral (Vol. 2). São Paulo, SP: Memnon.

Seabra, A. G., Trevisan, B. T., \& Capovilla, F. C. (2012). Teste infantil de nomeação. In A. G. Seabra \& N. M. Dias (Orgs.), Avaliação neuropsicológica cognitiva: Linguagem oral (Vol. 2, pp. 54-86). São Paulo, SP: Memnon.

Shaywitz, S. (2006). Entendendo a dislexia: Um novo e completo programa para todos os niveis de problemas de leitura. Porto Alegre, RS: Artmed.

Souza, T. N. U., \& Avila, C. R. B. (2011). Gravidade do transtorno fonológico, consciência fonológica e praxia articulatória em pré-escolares. Revista da Sociedade Brasileira de Fonoaudiologia, 16(2), 182-188. doi:10.1590/S1516-80342011000200012

Sternberg, R. J. (2008). Psicologia cognitiva (R. C. Costa, Trad., 4th ed.). Porto Alegre, RS: Artmed.

Storch, S. A., \& Whitehurst, G. J. (2002). Oral language and code-related precursors to reading: Evidence from a longitudinal structural model.Developmental Psychology, 38(6), 934-947. doi:10.1037/0012-1649.38.6.934

Trevisan, B. T. (2010). Atenção e controle inibitório em préescolares e correlação com indicadores de desatenção $e$ hiperatividade (Unpublished master's thesis). Universidade Presbiteriana Mackenzie, São Paulo, SP.

Trevisan, B. T., \& Seabra, A. G. (2012). Teste de trilhas para pré-escolares. In A. G. Seabra \& N. M. Dias (Orgs.), Avaliação neuropsicológica cognitiva: Atenção e funções executivas (Vol. 1, pp. 92-100). São Paulo, SP: Memnon.

Zorzi, J. L. (2009). A alfabetização: Uma proposta para ensinar crianças com dificuldades de aprendizagem. In J. Zorzi \& S. Capellini (Orgs.), Dislexia e outros distúrbios da leitura - escrita (pp. 149-194). São Paulo, SP: Pulso.

Talita de Cassia Batista Pazeto is an invited Professor of the Graduate Program in Psychopedagogy and a Ph.D. candidate of the Graduate Program in Developmental Disorders of the Universidade Presbiteriana Mackenzie.

Alessandra Gotuzo Seabra is a Professor of the Graduate Program in Developmental Disorders of the Universidade Presbiteriana Mackenzie.

Natália Martins Dias is a Professor of the Graduate Program in Educational Psychology of the Centro Universitário FIEO (UNIFIEO).

Received: Sep. 6, 2013

1st Revision: Feb. 1, 2014

2nd Revision: Mar. 29, 2014

Approved: June 30, 2014
How to cite this article:

Pazeto, T. C. B., Seabra, A. G., \& Dias, N. M. (2014). Executive functions, oral language and writing in preschool children: Development and correlations. Paidéia (Ribeirão Preto), 24(58), 213-221. doi: 10.1590/1982-43272458201409 


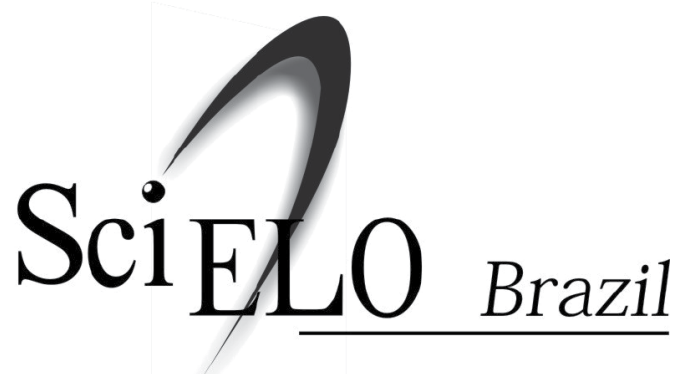
Paidéia (Ribeirão Preto) is a four-monthly publication available in full-text in the Scientific Electronic Library Online - SciELO.

The SciELO interface provides easy access to the tables of content and to the full-text articles.

The SciELO interface also provides the retrieval of articles by the author's name, the words from title, abstract and descriptors, in addition to providing bibliometric indicators and consultation indicators.

The articles are enriched with connections to the LILACS, MEDLINE and PubMed databases.

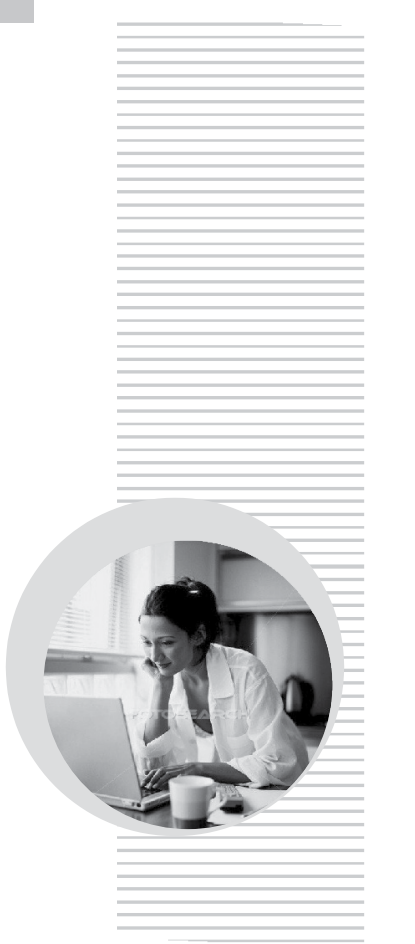

Paidéia (Ribeirão Preto) is a part of SciELO Brazil:

\section{www.scielo.br/paideia}

The SciELO interface provides access to a network of SciELO websites, gathering the major scientific journals of Latin America, Caribbean, Spain, Portugal and South Africa:

\section{www.scielo.org}

The electronic library is a project developed by the São Paulo Research Foundation (FAPESP), in partnership with the Latin American and Caribbean Center on Health Sciences Information (BIREME) and the National Council for Scientific and Technological Development (CNPq). 